\title{
ZARZĄDZANIE RYZYKIEM ORGANIZMÓW GENETYCZNIE ZMODYFIKOWANYCH W UNII EUROPEJSKIEJ
}

\author{
Monika Szkarłat \\ Uniwersytet Marii Curie-Skłodowskiej w Lublinie \\ Wydział Politologii, Zakład Stosunków Międzynarodowych \\ adres, e-mail: monikaszkarlat@gmail.com
}

\begin{abstract}
Streszczenie. Rozwój i upowszechnienie organizmów genetycznie zmodyfikowanych stanowi przedmiot debaty publicznej od prawie dwóch dekad. Tematem szczególnie istotnym jest ryzyko związane z komercjalizacją GMO, problem nieodwracalności i nieprzewidywalności skutków odłożonych w czasie. Dlatego wśród zagadnień poddawanych normatywizacji szczególne znaczenie zyskuje analiza i zarządzanie ryzykiem innowacji technologicznych. Przedmiotem artykułu jest analiza rozwiązań w obszarze zarządzania ryzykiem GMO wypracowanych przez Unię Europejską. Rozwiązania prawne przyjęte w UE są przykładem restrykcyjnego modelu zarządzania ryzykiem opartego na zasadzie ostrożności, rozproszeniu kompetencji pomiędzy poziom ponadnarodowy, państwowy, regionalny czy jednostkowy. Model ten jest przykładem zarówno procesu europeizacji $z$ widocznym efektem spill-over, jak również przeciweuropeizacji. Jest to ponadto przykład policentrycznego zarządzania, gdzie mamy do czynienia z integracją horyzontalną i wertykalną z udziałem wielu podmiotów.
\end{abstract}

Słowa kluczowe: organizmy genetycznie zmodyfikowane, Unia Europejska, zarządzanie ryzykiem, zasada ostrożności

\section{UWAGI WSTĘPNE}

Ryzyko stanowi przedmiot zainteresowania badaczy reprezentujących różne dyscypliny naukowe. W ramach prac badawczych nad istotą i specyfiką ryzyka od dawna podejmuj się próby zdefiniowania tego zjawiska, co doprowadziło do ogólnej konstatacji, iż nie można stworzyć jednej uniwersalnej definicji ryzyka. Poszukując najprostszego wyjaśnienia tego pojęcia można stwierdzić, że ryzyko to potencjalne zagrożenie, czy jak jest to ujęte w Słowniku wyrazów obcych PWN, „(...) możliwość, prawdopodobieństwo, że coś się nie uda, że sprawy przybiorą 
zły obrót”, „(...) działanie związane z jakimś niebezpieczeństwem, mogące przynieść niepożądane skutki; także podejmowanie takich działań".

Ryzyko należy postrzegać jako proces, nie jako stan, jako zjawisko wielowymiarowe, z których najważniejszy jest wymiar subiektywny i obiektywny. W tym sensie na pojęcie ryzyka będzie składać się jego percepcja (uwarunkowania kulturowe, społeczne, ekonomiczne i jednostkowe) oraz zawsze niekompletny zbiór danych, będących wynikiem zastosowania znanej w danym momencie metodologii i technik pomiaru. Analizując ryzyko należy też zwrócić uwagę na różnice poziomu akceptacji danego zagrożenia, co jest $\mathrm{m}$. in. konsekwencją prostego rachunku zysków i strat, ale także zaufania jednostek wobec autorytetów komunikujących, oceniających i zarządzających ryzykiem oraz poziomu upolitycznienia dyskusji o zagrożeniach. ${ }^{2}$

Można na ryzyko patrzeć z punktu widzenia szans i zagrożeń, jako na wyzwanie, prawdopodobieństwo, niepewność czy niebezpieczeństwo. Jak podkreśla U. Beck ryzyko jest zawsze pozycjonowane w przyszłości, odnosi się do wydarzeń przyszłych, które mogą, ale nie muszą mieć miejsca: „Ryzyko ma postać postrzeżeniowych i myślowych szablonów dynamiki mobilizującej społeczeństwo wobec otwartości, niepewności i blokad tworzonej przez nie przyszłości". ${ }^{3}$ Z definicji U. Beck'a wynika, że jest ono bytem o charakterze subiektywnym, a społeczeństwo uczestniczy w jego tworzeniu. Prowadząc analizę ryzyka jako kategorii socjologicznej Beck wprowadził do nauki pojęcie społeczeństwa ryzyka oraz społeczeństwa globalnego ryzyka. Doszedł do wniosku, iż społeczeństwo ryzyka, jako społeczeństwo nowoczesne, korzystające z efektów modernizacji paradoksalnie - musi stale zmagać się z niepewnością oraz wszechobecnością nie w pełni definiowalnych zagrożeń. Zaawansowanie technologiczne i nieustanny postęp nauki nie pociąga za sobą zmniejszenia liczby i wpływu zagrożeń na życie człowieka. Stałym konstruktem, kodem genetycznym społeczeństwa ryzyka jest coraz wyższa świadomość ryzyka, które staje się dostrzegalne dla zbiorowości. Jak stwierdza autor ,(k)ategoria ryzyka obejmuje więc obcowanie z niepewnością, której przyrost wiedzy często nie tylko nie potrafi dziś przezwyciężyć, lecz ją właśnie powoduje". ${ }^{4}$

Społeczeństwo postnowoczesne to społeczeństwo globalnego ryzyka, gdyż dyskusja o ryzyku, jego skali oraz strategiach zapobiegania stanowi stały element egzystencji. W zależności od szerokości geograficznej można różnie postrzegać te same zagrożenia, inaczej na nie reagować, ale to co łączy ludzkość to świadomość permanentnego występowania zagrożeń, jak też - parafrazując sentencję przypisywaną Sokratesowi - wiedza o tym, że się nie wie, czego się nie wie.

1 Słownik wyrazów obcych PWN, Wydawnictwo Naukowe PWN, Warszawa 2006.

2 L. F. Clark, Framing the Uncertainty of Risk: Models of Governance for Genetically Modified Foods, „Science and Public Policy” August 2013, Vol. 40, No. 4, s. 480-481.

3 U. Beck, Społeczeństwo światowego ryzyka. W poszukiwaniu utraconego bezpieczeństwa, Wyd. Naukowe Scholar, Warszawa 2012, s. 15.

${ }^{4}$ U. Beck, op. cit., s. 17. 
Globalne ryzyko wyróżniają trzy cechy: 1) deterytorializacja, 2) niewyliczalność - niewiedza/nieświadomość skutków odłożonych w czasie, 3) nienaprawialność. Jak podkreśla U. Beck ,Życie w społeczeństwie światowego ryzyka oznacza życie $\mathrm{z}$ nieusuwalną niewiedzą, a ściślej: życie w obliczu jednoczesności zagrożeń i niewiedzy wraz z wynikającymi stąd politycznymi, społecznymi i moralnymi paradoksami i dylematami". ${ }^{5}$ Tworzy to istotne wyzwanie dla instytucji państwa oraz szerzej społeczności międzynarodowej, która musi mierzyć się z problemem standaryzacji i przyjęcia skutecznych modeli międzynarodowego zarządzania zagrożeniami. Im większe jest prawdopodobieństwo ryzyka o poważnych skutkach, tym większe wyzwanie dla procesu decyzyjnego. Warto podkreślić, iż w obliczu zagrożeń, np. ekologicznych czy technologicznych, można obserwować dewaluację znaczenia państwa narodowego w procesie standaryzacji i zarządzania ryzykiem, a jednocześnie wzrost roli instytucji i reżimów międzynarodowych. ${ }^{6}$

Obecnie często poruszanym tematem, zarówno w badaniach nad ryzykiem jak też w debacie publicznej, są zagrożenia wynikające z szybkiego postępu naukowo-technicznego. Współcześnie żyjący niemal codziennie stają się świadkami kolejnych osiągnięć naukowych, a ludzkość zyskuje dostęp do nowoczesnych rozwiązań technologicznych, które z założenia mają czynić życie łatwiejszym, bardziej komfortowym i bezpiecznym. $Z$ drugiej strony, pojawia się refleksja, iż wiele $\mathrm{z}$ innowacji $\mathrm{w}$ dziedzinie nauk ścisłych czy przyrodniczych wraz z zaspokajaniem potrzeb ludzkości może jednocześnie służyć jako narzędzie destrukcji. Badacze ryzyka technologicznego przestrzegają przed podwójną naturą wielu rozwiązań, których bezpieczeństwo jest co najwyżej prawdopodobne, a nie faktyczne. Podkreślają też, że technologie uważane do tej pory za nieszkodliwe mogą - w wyniku postępu wiedzy - okazać się potencjalnym zagrożeniem. To sprawia, że coraz bardziej świadoma opinia publiczna podchodzi z rezerwą do kolejnych osiągnięć technologicznych, wiedząc, że ryzyko wiąże się nie tyle z samym procesem niewłaściwego użytkowania innowacji, ale niewiedzą jakie są tego długofalowe skutki. Wyniki badań prowadzonych przez B. Wynne wskazują, że konsumenci kolejnych aplikacji technologicznych poszerzają swoją wiedzę na temat specyfiki technologii, co jednak nie przekłada się na wzrost zaufania społecznego dla postępu technologicznego. Natomiast istotnym czynnikiem sprzyjającym jest transparentność procesu decyzyjnego prowadzącego do ustalenia ram instytucjonalno-prawnych zarządzania rynkiem innowacji. Podobną tezę - choć o bardziej

5 Ibidem, s. 170.

6 Ibidem, s. 75-82. Ryzyko definiowane jako funkcja niepewności, braku pełnej wiedzy o zagrożeniu, Zob. T. Aven, Quantitative Risk Assessment. The Scientific Platform, Cambridge University Press, New York 2011, s. 20.

7 Szerzej: B. Wynne, May the Sheep Safely Graze? A Reflexive View of the Expert-Lay Knowledge Divide, [in:] Risk, Environment and Modernity. Towards a New Ecology, ed. by S. Lash, B. Szerszynski, B. Wynne, SAGE Publication Ltd., London 1996, s. 57 i n. 
kategorycznym wydźwięku - stawia U. Beck, stwierdzając: „(...) w sprawach zagrożeń nikt nie jest ekspertem, eksperci - zwłaszcza oni - także nie". ${ }^{8}$

Niedoskonałość zobiektywizowanego pomiaru ryzyka nowoczesnych technologii polega na tym, że badacz dysponuje tylko obecnie dostępnym instrumentarium technik pomiaru i założeń metodologicznych. Postęp nauki wraz z kolejnymi innowacjami niesie również bardziej precyzyjne metody analityczne. Istotny jest kontekst procesualny postępu naukowego, w ramach którego - jak to określił J. Arnoldi - możliwe jest przekształcenie nieznanych niewiadomych w znane niewiadome, a następnie w zdefiniowane zagrożenia. Tu najistotniejszy jest czynnik czasu, nad którym można zapanować poprzez ustalenie skutecznych procedur zarządzania niepewnością i ryzykiem. Nie jest rozwiązaniem wstrzymywanie rozwoju technologicznego tylko z uwagi na niepewność jego konsekwencji w perspektywie długoterminowej. Takie działanie jest bezzasadne również dlatego, że - paradoksalnie - pełne zidentyfikowanie katalogu szans i zagrożeń danej innowacji jest możliwe wyłącznie poprzez jej powszechne stosowanie w dhuższym okresie czasu. ${ }^{9}$

Dotychczas prowadzone badania dostarczają bogatej wiedzy na temat kategoryzacji ryzyka, percepcji, ewaluacji/oceny, strategii zarządzania i komunikowania o ryzyku. Naukowcy z Harwardzkiego Centrum Badań nad Ryzykiem dokonali analizy prawie 3000 rodzajów ryzyka, dzieląc je zgodnie z kryterium źródła, przyczyny ryzyka lub skutku i tworząc dzięki temu tzw. przestrzeń ryzyka. Zgodnie z pierwszym kryterium wyodrębniono 18 kategorii ryzyka, w których mieszczą się poszczególne zagrożenia $\mathrm{z}$ listy $2878, \mathrm{w}$ tym $\mathrm{m}$. in. przemoc i przestępczość, alkohol, tytoń i inne używki, leki i zabiegi medyczne, transport, wojna, terroryzm, substancje toksyczne, żywność i rolnictwo, zanieczyszczenie powietrza, zagrożenia polityczne, społeczne, finansowe, ekogeologiczne, globalne, choroby i inne zagrożenia dla zdrowia ludzi, związane $\mathrm{z}$ wykonywaną pracą itd. Kategoryzacja według kryterium skutku składa się z trzech wyodrębnionych zbiorów: ryzyko ekologiczne, ryzyko dla zdrowia lub ryzyko dla bezpieczeństwa. Zagrożenia dla bezpieczeństwa i zdrowia dotykają człowieka bezpośrednio, natomiast zagrożenia ekologiczne dotyczą w pierwszej kolejności organizmów innych niż człowiek. ${ }^{10}$

Definicja ryzyka podlegała ewolucji na przestrzeni czasu. Wpływają na to rozszerzający się zakres zobiektywizowanych narzędzi pomiaru ryzyka, ale również zmiany w czynnikach społecznych, ekonomicznych czy kulturowych postrzegania ryzyka. Era industrializacji sprawiła, że przeniesiono punkt ciężkości z postrzegania ryzyka przede wszystkim jako konsekwencji procesów/zjawisk naturalnych, na które człowiek ma niewielki wpływ, lub jako efekt działania sił pozaziemskich. W erze postindustrialnej czy ponowoczesnej znacznie większa liczba zagrożeń

8 U. Beck, op. cit., s. 58.

9 J. Arnoldi, Ryzyko, przeł. B. Reszuta, Wyd. Sic, Warszawa 2011, s. 114.

10 Szerzej: J. K. Hammitt, J. B. Wiener, B. Swedlow, D. Kall, Z. Zhou, Precautionary Regulation in Europe and the United States: A Quantitative Comparison, "Risk Analysis" October 2005, Vol. 25, No. 5, s. 1217-1220. 
ma charakter antropogeniczny, będąc skutkiem wykorzystania produktów postępu technologicznego. Przykładem może być zastosowanie organizmów genetycznie zmodyfikowanych w rolnictwie, produkcji żywności, medycynie czy licznych branżach przemysłu. Rozwijają się studia nad istotą pojęcia niepewności ${ }^{11}$, które jest trudno mierzalne przy użyciu metod ilościowych, a częściej stosuje się metody stochastyczne. Na znaczeniu zyskują czynniki subiektywne, które postuluje się uwzględniać w kompleksowym procesie oceny ryzyka. ${ }^{12}$

Wpływ na percepcję ryzyka związanego $\mathrm{z}$ wdrażaniem innowacji technologicznych - jak już wspomniano - mają czynniki społeczne, ekonomiczne czy kulturowe. Konsumenci technologii w zdecydowanej większości nie posiadają specjalistycznej wiedzy naukowej na temat specyfiki produktów technologii, dlatego możliwość oceny szans i zagrożeń opierają na alternatywnych podstawach. ${ }^{13}$ Sposób definiowania ryzyka innowacji przez jej użytkowników przekłada się na poziom upowszechnienia danego produktu czy rozwiązania. Badania dowodzą, iż ludzki umysł nie posiada zdolności tworzenia ,tablic rankingowych” różnych typów ryzyka w oparciu o dostarczone dane, oceniających statystyczne prawdopodobieństwo ich zaistnienia. ${ }^{14}$ Mniej obawiamy się zagrożeń związanych z życiem codziennym, niż takich, których wystąpienie jest mało prawdopodobne, np. katastrofa lotnicza. Jako bardziej ryzykowne określamy te zjawiska, które zostają nam narzucone, np. dopuszczenie obrotu żywności transgenicznej na rynku wewnętrznym UE, niż stanowiące efekt własnego wyboru, np. używanie narkotyków czy palenie papierosów. Perspektywa nagrody jest też czynnikiem skłaniającym do podejmowania wyższego ryzyka. To tłumaczy większą akceptację dla stosowania inżynierii genetycznej w medycynie oraz brak zgody na modyfikację genetyczną produktów z przeznaczeniem na żywność. Im mamy wyższe oczekiwania związane $\mathrm{z}$ nową technologią (np. wynalezienie leku na chorobę terminalną), tym więcej jesteśmy skłonni poświęcić dla realizacji celu (np. zgoda na testy na zwierzętach) oraz tym mniejsze ryzyko wiążemy z wprowadzeniem produktu końcowego. ${ }^{15}$

${ }^{11}$ B. Wynne podkreśla, że niepewność może przybrać różne formy, np. niepewność co do prawdopodobieństwa wystąpienia znanego czynnika, ignorancja potencjalnych efektów czy nieprzewidywalność tzw. czynnika ludzkiego. Zob. S. Carr, L. Levidow, Exploring the Links Between Science, Risk, Uncertainty, and Ethics in Regulatory Controversies about Genetically Modified Crops, ,Journal of Agricultural and Environmental Ethics” 2000, Vol. 12, Issue 1, s. 32.

${ }^{12}$ Ibidem, s. 480.

${ }^{13}$ L. Busch, The Homiletics of Risk, „Journal of Agricultural and Environmental Ethics” 2002, Vol. 15, Issue 1, s. 27.

${ }^{14}$ Całkowicie zobiektywizowane podejście do technologii i związanych z nią zagrożeń jest niemożliwe, ponieważ wszystkie badania prowadzone są przez ludzi (ryzyko błędu), którzy funkcjonują w przestrzeni wartości, kodów kulturowych. Szerzej: M. Decker, A. Grunwald, Rational Technology Assessment as Interdisciplinary Research, [in:] Interdisciplinarity in Technology Assessment. Implementation and its Chances and Limits, ed. by M. Decker, Wissenschaftsethik und Technikfolgenbeurteilung, Band 11, Springer, Berlin, Heidelberg, New York 2001, s. 67-68.

${ }^{15}$ M. Wicha, Spoleczna percepcja żywności genetycznie zmodyfikowanej - analiza porównawcza na przykładzie wybranych państw, „Pamiętnik Puławski” 2009, Zeszyt 151/I, s. 395. 
Istotnym ograniczeniem możliwości zdefiniowania ryzyka związanego z nowymi technologiami jest nie tylko brak wiedzy na temat długofalowych skutków powszechnego stosowania innowacji, ale również fakt, że technologie takie jak biotechnologia czy nanotechnologia są w procesie intensywnego rozwoju, co sprawia, że zbiór obiektywnych danych o ich specyfice nie jest zamknięty. Konsumenci uznają za obarczone większym ryzykiem te technologie, których katalog szans i zagrożeń nie jest możliwy do zdefiniowania dla ekspertów. Rozbieżność stanowisk gremiów opiniotwórczych oraz brak zaufania do instytucji odpowiedzialnych za zarządzanie ryzykiem stanowi kolejny czynnik zwiększający subiektywne postrzeganie zagrożenia. ${ }^{16}$

Znaczenie mają ponadto uwarunkowania kulturowe, pośród których można wymienić system wartości etycznych, światopogląd czy wyznawaną religię. Zwolennicy porządku świata opierającego się na dominacji/panowaniu człowieka nad przyrodą cechują się wyższym progiem tolerancji dla ingerencji człowieka w ekosystem, jeśli ma to służyć dobru ludzkości. Ta grupa jest skłonna zaakceptować ryzyko ewentualnych zmian w bioróżnorodności wywołanych użytkowaniem technologii, która poprawia jakość życia człowieka. Percepcja ryzyka zależy też od czynników socjoekonomicznych i demograficznych, takich jak wiek, pochodzenie etniczne, miejsce zamieszkania, dochód czy płeć. Większym progiem tolerancji dla nowości, niepewności i braku pełnej wiedzy o zagrożeniach wynikających z nowych technologii cechują się ludzie młodzi, z wyższym wykształceniem, mężczyźni. Kobiety z zasady podchodzą z dystansem do innowacji w sektorze produkcji żywności, ponieważ to one w większości przypadków ponoszą odpowiedzialność za żywienie rodziny (zakupy, przygotowanie posiłków czy produkcja żywności). Percepcja ryzyka innowacji technologicznych zależy również od zaufania konsumentów technologii do podmiotów oceniających i zarządzających ryzykiem. ${ }^{17}$

\section{OCENA I ZARZĄDZANIE RYZYKIEM TECHNOLOGII - WYMIAR NORMATYWNY}

Wielość definicji ryzyka, także tego związanego z nowymi technologiami, czynnik niepewności, świadomość braku pełnej wiedzy na temat specyfiki zagrożeń oraz wpływ czynników społecznych, ekonomicznych, politycznych czy kulturowych sprawia, że proces oceny i zarządzania ryzykiem stanowi wyzwanie dla twórców norm prawnych zarówno na poziomie prawa krajowego, jak też międzynarodowego. Dlatego W. Ruckelshaus stwierdził, że ocena ryzyka (ang. risk assessment) to „małżeństwo pod przymusem pomiędzy nauką a prawem”, czy

\footnotetext{
${ }^{16}$ Ibidem, s. 396 i n.

${ }^{17}$ M. Wicha, op. cit., s. 399-402.
} 
jak zdefiniowano to w innym miejscu - techniczne wsparcie procesu decyzyjnego w warunkach permanentnej niepewności. ${ }^{18}$

Od prawodawcy oczekuje się, że poprzez działania normotwórcze uda się wypracować modus operandi, na który składać się będą instrumenty pozwalające niwelować ewentualne skutki uboczne używania innowacji, pozwalające zapobiegać tym, których nie znamy, ale które mogą zaistnieć w przyszłości, a jednocześnie umożliwiające nieograniczone korzystanie z postępu technologicznego. Istotnym jest, aby poprzez zbyt restrykcyjne przepisy nie doprowadzić do zahamowania postępu, ale również aby brak regulacji czy nadmiernie liberalny charakter rozwiązań nie spowodował utraty kontroli nad pracami badawczymi i komercjalizacją innowacji.

Kompleksowy system oceny ryzyka innowacji powinien uwzględniać zarówno analizę danych obiektywnych, takich jak badania laboratoryjne, testy polowe, czy epidemiologiczne itp., ale też subiektywnych oraz uwarunkowań społecznych, kulturowych, ekonomicznych, czy kontekstu politycznego. Na podstawie dokonywanej regularnie oceny ryzyka wdrażane są działania określane jako zarządzanie ryzykiem (ang. risk management). Dodatkowym - lecz nie mniej ważnym - jest komunikowanie/informowanie o ryzyku (ang. risk communication). ${ }^{19}$ Jednocześnie należy wskazać, że pojęcie zarządzania ryzykiem (ang. risk governance) jest również używane na określenie procesu tworzenia i implementacji norm prawa, mających zastosowanie do konkretnego problemu. Identyfikacja modelu zarządzania uwzględnia analizę całego systemu, poczynając od identyfikacji podmiotów zaangażowanych w proces (zarówno formalnych, jak i nieformalnych), procesu decyzyjnego oraz implementacji decyzji i jej skutków. Pierwszym etapem jest ewaluacja ryzyka na podstawie dostępnych danych zobiektywizowanych, konsultacji z interesariuszami i uwzględnieniu kontekstu społecznego, kulturowego, ekonomicznego i politycznego. Proces decyzyjny ma dać odpowiedź nie tylko na pytanie jak ośrodek decyzyjny postrzega dane zjawisko i związane z nim szanse i zagrożenia, ale również jaki będzie model kontroli, jak zostaną rozdzielone kompetencje czy odpowiedzialność.

Wiedza pochodząca od ekspertów, uwzględniająca aktualne wyniki badań naukowych czy dane statystyczne, jest niewystarczająca w procesie ewaluacji ryzyka nowych technologii. Ma to związek z samą specyfiką innowacji, które obarczone są wysokim wskaźnikiem nieprzewidywalności skutków w odległej przyszłości, ale również brakiem zaufania opinii publicznej do gremiów eksperckich. Ten ostatni czynnik jest szczególnie widoczny w przypadku innowacji, które budzą kontrowersje, przez co przedstawiciele świata nauki wyrażają sprzeczne

${ }^{18}$ G. W. Suter II, Ecological Risk Assessment, $2^{\text {nd }}$ Edition, CRC Press, Taylor \& Francis Group 2007, s. 4.

${ }^{19}$ D. Brown, Environmental Risk Assessment and Management of Chemicals, [in:] Risk Assessment and Risk Management. Issues in Environmental Science and Technology, 9, ed. by R. E. Hester, R. M. Harrison, The Royal Society of Chemistry 1998, s. 91-92. 
opinie na temat ryzyka technologii. Jednym z rozwiązań tej sytuacji, aczkolwiek niedoskonałym, jest uwzględnienie zasady ostrożności/przezorności w procesie zarządzania ryzykiem.

Zasada ta została zdefiniowana w Deklaracji z Rio w sprawie środowiska i rozwoju, przyjętej na Konferencji Narodów Zjednoczonych „Środowisko i rozwój" w dn. 3-14 czerwca 1992 r. w Rio de Janeiro. Zasada 15 Deklaracji brzmi: „Wszystkie państwa powinny szeroko stosować działania zapobiegawcze dotyczące ochrony środowiska, mając na uwadze ich własne możliwości w tym zakresie. Tam, gdzie występuje zagrożenie poważnymi lub nieodwracalnymi zmianami w środowisku, brak co do tego całkowitej, naukowej pewności nie może być powodem opóźnienia efektywnych działań, których realizacja zapobiegałaby degradacji środowiska". ${ }^{20}$

Szczyt Ziemi w Rio de Janeiro nie był pierwszym forum międzynarodowym, na którym dyskutowano o konieczności uwzględnienia w procesie decyzyjnym zasady przezorności. Przyjęta w 1982 r. Światowa Karta na rzecz Natury zawierała odwołanie do zasady ostrożności. Podkreślano jej znaczenie w trakcie międzynarodowych spotkań poświęconych zanieczyszczeniu mórz i oceanów, kontroli zasobów morskich i utrzymaniu bioróżnorodności akwakultur. Koncepcję przezorności zaczęto uwzględniać w innych politykach publicznych - zarówno na poziomie państwowym jak również supranarodowym. Dla przykładu, Niemcy postulowały, aby zasadę ostrożności włączyć do katalogu zasad prawa wspólnotowego, mającą zastosowanie do polityki ochrony środowiska UE. Udało się tego dokonać i zasada została włączona do prawa wspólnotowego na podstawie Traktatu z Maastricht z 1992 r. (art. 174). W kolejnych latach zasada była włączana do szeregu dokumentów prawnomiędzynarodowych, w tym $\mathrm{m}$. in. stanowi istotną regułę mechanizmu oceny ryzyka żywych zmodyfikowanych organizmów, ustanowioną w Protokole Kartageńskim o bezpieczeństwie biologicznym $(2000 \text { r. })^{21}$, dołączonym do Konwencji o różnorodności biologicznej z Rio de Janeiro (1992 r.). W punkcie 4 Aneksu III Protokołu znajduje się odwołanie do zasady ostrożności w brzmieniu z Deklaracji z Rio. ${ }^{22}$

Zasada ostrożności szybko stała się orężem w rękach opinii publicznej przeciwko instytucjom posiadającym legitymację do stanowienia i egzekwowania prawa, podmiotom odpowiedzialnym za szacowanie i kontrolę ryzyka, naukowcom pracującym nad innowacyjnymi technologiami oraz przemysłem. Dzięki znacznie łatwiejszemu dostępowi do informacji zwykli użytkownicy technologii mogli poszerzyć swoją wiedzę o procesie tworzenia i komercjalizacji innowacji.

${ }^{20}$ Deklaracji z Rio w sprawie środowiska i rozwoju, Konferencja Narodów Zjednoczonych „Środowisko i Rozwój”" na posiedzeniu w Rio de Janeiro w dniach od 3 do 14 czerwca 1992 r., URL < http://libr.sejm.gov.pl/tek01/txt/inne/1992.html>, dostęp z dnia 20.08.2015.

${ }^{21}$ Cartagena Protocol on Biosafety to the Convention on Biological Diversity. Text and Annexes, Montreal 2000, URL <http://bch.cbd.int/protocol/text/>, dostęp z dnia 20.08.2015.

${ }^{22}$ Szerzej o znaczeniu Protokołu Kartageńskiego: M. Szkarłat, Żywność genetycznie zmodyfikowana w stosunkach międzynarodowych, Wydawnictwo UMCS, Lublin 2011, s. 322-332. 
Transparentność i dostęp do informacji skutkował również rosnącym sceptycyzmem oraz kontestacją dotychczasowego przeświadczenia o nieomylności świata nauki czy skuteczności mechanizmów legislacyjnych w kontekście niwelowania ryzyka związanego z nowymi technologiami. W efekcie postulowano coraz szersze stosowanie zasady ostrożności w procesie decyzyjnym, co spotykało się z krytyką części środowiska naukowego. Podnosili oni argument, iż zasada ostrożności nie ma waloru naukowego, jest trudna do skwantyfikowania, a im bardziej rozwiązania prawne są na niej oparte, tym mniej miejsca dla wnioskowania naukowego. Pojawiły się też głosy, że zasada ostrożności jest przede wszystkim instrumentem wprowadzania ograniczeń w handlu. Ten argument jest często podnoszony w debacie o zasadach transatlantyckiej wymiany handlowej. $Z$ drugiej strony, zwolennicy upowszechnienia zasady ostrożności i nadania jej statusu normy prawnej wskazują, iż poprzez jej obecność w systemach prawnych możliwe jest poszerzenie grona podmiotów mających wpływ na zarządzanie ryzykiem technologii, np. o organizacje pozarządowe reprezentujące interesy konsumentów, ekologiczne itd. Podkreślają, na co również zwraca uwagę Komisja Europejska w swoich dokumentach poświęconych zasadzie ostrożności, iż granice jej stosowania wyznacza sama nauka. Mianowicie, im więcej danych pochodzących z badań naukowych, im większa spójność wyników badań, tym mniejsza konieczność po stronie ośrodka decyzyjnego, aby odwoływać się do zasady ostrożności. ${ }^{23}$

Zdaniem części badaczy zajmujących się znaczeniem i wpływem zasady ostrożności na funkcjonowanie systemów zarządzania ryzykiem technologii, uwzględnienie zasady w procesie decyzyjnym nie odniosło spodziewanych efektów. Po pierwsze, kontrowersje wokół niektórych technologii są nadal na tym samym poziomie. Po drugie, zasada ostrożności nie stała się czynnikiem sprzyjającym wzrostowi zaufania opinii publicznej wobec twórców i wykonawców przepisów dotyczących zarządzania ryzykiem technologii. ${ }^{24}$

\section{ZARZĄDZANIE RYZYKIEM ORGANIZMÓW GENETYCZNIE ZMODYFIKOWANYCH - MODEL EUROPEJSKI}

Organizmy genetycznie zmodyfikowane, otrzymywane poprzez wykorzystanie inżynierii genetycznej, znajdują coraz szersze zastosowanie w różnych dziedzinach życia. Od lat 90 . XX wieku trwa proces komercjalizacji roślin transgenicznych, a światowy areał upraw tych odmian systematycznie rośnie. Transgeniczne rośliny, zwierzęta i mikroorganizmy są produkowane bezpośrednio do

${ }^{23}$ R. E. Löfstedt, B. Fischhoff, I. R. Fischhoff, Precautionary Principles: General Definitions and Specific Applications to Genetically Modified Organisms, "Journal of Policy Analysis and Management" Summer 2002, Vol. 21, Issue 3, s. 384-386.

${ }^{24}$ O. Todt, J. L. Luján, Analyzing Precautionary Regulation: Do Precaution, Science, and Innovation Go Together?, "Risk Analysis" December 2014, Vol. 34, Issue 12, s. 2165-2166. 
celów spożywczych lub stanowią półprodukt dla przemysłu rolno-spożywczego. Inne zastosowania to przemysł chemiczny, farmaceutyczny, medycyna, produkcja pasz zwierzęcych czy ochrona środowiska. Nieustanny rozwój technologii i rozszerzanie obszarów stosowania jej produktów wymusza na podmiotach tworzących prawo niezwykłą czujność i ciągłe starania, aby istniejące standardy były aktualizowane i dostosowywane do rzeczywistości. Dotyczy to w pierwszej kolejności podmiotów międzynarodowych, które wyznaczają kierunki zmian, za którymi następnie podążają organy ustawodawcze w poszczególnych państwach.

Kontrowersje, jakie nadal budzi biotechnologia i jej aplikacja, np. w postaci organizmów genetycznie zmodyfikowanych, niewątpliwie stanowią jedną $\mathrm{z}$ istotnych trudności $\mathrm{w}$ procesie tworzenia uniwersalnych zasad i norm. Należy pogodzić interesy zwolenników i przeciwników GMO, obawy konsumentów o nieprzewidywalność skutków odłożonych w czasie, postulaty przedstawicieli świata nauki, aby nie blokować postępu naukowego i tym samym nie narażać się na skutki tzw. błędu zaniechania, eksporterów i importerów GMO (głównie produkty roślinne).

Dlatego wymiar prawnomiędzynarodowy GMO stanowi skomplikowaną, wielopoziomową, wielosektorową układankę, będącą systemem naczyń połączonych. Standardy wypracowane w ramach systemu Organizacji Narodów Zjednoczonych to regulacje dotyczące zarówno handlu międzynarodowego, bezpieczeństwa żywnościowego i bezpieczeństwa żywności, badań naukowych i innowacji, ochrony własności intelektualnej czy poszanowania bioróżnorodności. We wszystkich wymienionych działach prawa międzynarodowego odnajdziemy akty i dokumenty stricte regulujące wykorzystanie GMO. Najważniejsze to Konwencja o różnorodności biologicznej (1992 r.) i dołączony do niej Protokół Kartageński o bezpieczeństwie biologicznym (2000 r.), wynegocjowany i przyjęty przez Organizację NZ ds. Żywności i Rolnictwa (FAO) Międzynarodowy traktat o zasobach genetycznych roślin dla wyżywienia i rolnictwa (2001 r.), standardy i wytyczne Komisji Codex Alimentarius, porozumienia w ramach Światowej Organizacji Handlu (WTO) (Porozumienie w sprawie barier technicznych w handlu, Porozumienie w sprawie stosowania środków sanitarnych i fitosanitarnych, Porozumienie w sprawie handlowych aspektów praw własności intelektualnej - wszystkie z 1994 r.), Międzynarodowa konwencja na rzecz ochrony nowych gatunków roślin (przyjęta w ramach UPOV, ostatnia rewizja w 1991 r.) czy zalecenia, rekomendacje i wytyczne OECD. ${ }^{25}$

Regulacje prawnomiędzynarodowe zawierające normy bezpośrednio lub pośrednio odnoszące się do GMO można obecnie odnaleźć w pięciu międzynarodowych reżimach normatywnych: handlowym, ochrony środowiska naturalnego, bezpieczeństwa żywnościowego, własności intelektualnej i poniekąd również w międzynarodowym systemie ochrony praw człowieka. Dodatkowo, w literaturze poświęconej zagadnieniom normatywizacji aplikacji nowoczesnej

${ }^{25}$ Szerzej: M. Szkarłat, op. cit., s. 322-363. 
biotechnologii część autorów wskazuje i wyróżnia system wypracowany w Unii Europejskiej jako odrębny. Przepisy prawa UE w omawianym obszarze są uznawane za jedne z najbardziej restrykcyjnych na świecie, a stosunek europejskiej opinii publicznej wobec GMO za - od wielu lat - niezmiennie negatywny. Są to jednak tylko uogólnienia.

Należy podkreślić, iż rzeczywiście prawo UE stanowi pewien specyficzny porządek prawny, ale funkcjonujący w ramach prawa międzynarodowego. Jest to przykład tzw. struktury hybrydowej, która zarówno pod względem specyfiki prawa jak i systemu instytucjonalnego posiada jednocześnie cechy organizacji międzynarodowej i państwa. Państwa członkowskie rezygnując z części uprawnień przenoszą je na poziom ponadnarodowy, a jednocześnie silnie obecna jest współpraca transnarodowa, poczynając od najniższego szczebla. Procesy europeizacji prowadzą do zacieśniania kooperacji, konstytucjonalizacji prawa UE i pojawienia się - jak to określił C. Scott - postregulacyjnego państwa. ${ }^{26}$ Zjawisko delegowania kompetencji czy pomijania państwa w procesie decyzyjnym miesza się z przykładami renacjonalizacji kompetencji. UE jest transnarodowym systemem decyzyjnym, czy jak to definiują przedstawiciele koncepcji wielopoziomowego zarządzania - przykładem zarządzania policentrycznego, gdzie proces decyzyjny przebiega w wymiarze wertykalnym i horyzontalnym, a podmioty uczestniczące to zarówno uczestnicy formalni i nieformalni z poziomu ponadnarodowego, narodowego, regionalnego czy lokalnego. ${ }^{27}$

Powstaje pytanie, czy wymienione powyżej cechy znajdują potwierdzenie w funkcjonującym w UE modelu zarządzania ryzykiem GMO? Zanim zostanie podjęta próba odpowiedzi na to pytanie oraz przedstawienie założeń modelu należy zwrócić uwagę na kilka istotnych determinant. Pomimo utrzymującego się sceptycyzmu obywateli państw członkowskich wobec GMO oraz oczekiwań, że żywność transgeniczna nie będzie sprzedawana w UE, a odmiany roślin genetycznie zmienionych nie będą uprawiane przez europejskich rolników, nie jest możliwe przyjęcie przepisów jednoznacznie zakazujących GMO w UE. Ma to związek ze zobowiązaniami prawnomiędzynarodowymi UE, z których jednoznacznie wynika, iż np. zakazywanie czy nieuzasadnione utrudnianie importu GMO do UE jest naruszeniem zasad handlu międzynarodowego. Światowa Organizacja Handlu wymaga od swoich członków, aby proces analizy ryzyka produktów biotechnologicznych opierał się na dowodach naukowych. Kolejnym czynnikiem są też widoczne rozbieżności pomiędzy państwami członkowskimi i wewnątrz nich. Polaryzacja stanowisk przyczynia się, jeśli nie do blokowania procesu decyzyjnego na poziomie instytucji UE, to do „kreatywnego” interpretowania przepisów

${ }^{26}$ M. Chowdhury, R. A. Wessel, Conceptualizing Multilevel Regulation in the EU: A Legal Translation of Multilevel Governance, "European Law Journal” May 2012, Vol. 18, No. 3, s. 337.

${ }^{27}$ J. Ruszkowski, Governance i jego typy w systemie wielopoziomowym. Zamiast wstepu, [w:] Multi-level governance w Unii Europejskiej, red. J. Ruszkowski, L. Wojnicz, SzczecinWarszawa 2013, s. 7 i n. 
wspólnotowych na poziomie państwowym lub nawet przypadków świadomego zaniechania ich implementacji. Regulacje wspólnotowe dotyczące GMO mają charakter wielosektorowy, gdyż przecinają kilka polityk szczegółowych UE: funkcjonowanie rynku wewnętrznego, wspólna polityka rolna, bezpieczeństwo żywności, zdrowie publiczne, ochrona konsumentów czy badania i rozwój technologiczny. To wymaga pogodzenia często sprzecznych interesów i zasad funkcjonowania polityk. Elementem łączącym jest oparcie zarządzania ryzykiem o zasadę ostrożności, która stała się jedną z zasad prawa UE. ${ }^{28}$ Czynnikiem, który musi być brany pod uwagę jest utrzymujący się brak zaufania obywateli państw członkowskich do instytucji wspólnotowych i krajowych oceniających i zarządzających ryzykiem. Jest to konsekwencja $m$. in. kilku poważnych kryzysów, np. epidemia BSE czy pryszczycy. Silna polaryzacja poglądów nie sprzyja rzeczowej debacie, co skutkuje znaczącym upolitycznieniem procesu decyzyjnego, pojawianiu się postulatów renacjonalizacji kompetencji i oparcia systemu zarządzania ryzykiem na dość radykalnej interpretacji zasady ostrożności, czyli zahamowaniu rozwoju technologii do momentu uzyskania pewności co do jej bezpieczeństwa.

Instytucjonalizacja zasady ostrożności to nie jedyna wspólna cecha procedur zarządzania ryzykiem w UE. Poza tym, system ten wyróżnia się znaczącą fragmentaryzacją kompetencji, udziałem licznych gremiów eksperckich ustrukturalizowanych w formie komitetów, agencji unijnych, niezależnych think tanków czy grup roboczych; proces decyzyjny na poziomie wspólnotowym dzielony jest według zasady: akty prawodawcze o charakterze podstawowym przyjmowane są w zwykłej procedurze prawodawczej, akty o charakterze wykonawczym w procedurze komitologii; upolitycznienie i blokowanie procesu decyzyjnego na poziomie Rady oraz brakiem transparentności szczególnie dla zwykłych użytkowników technologii.

Podstawy traktatowe przepisów prawa wtórnego dotyczących GMO to w szczególności art. 43 Traktatu o funkcjonowaniu Unii Europejskiej (TFUE) (polityka rolna UE), art. 114 TFUE (zbliżanie ustawodawstw, funkcjonowanie rynku wewnętrznego UE), art. 168 (4b) TFUE (zdrowie publiczne), art. 169 TFUE (ochrona konsumentów), art. 191 (2) TFUE (zasada ostrożności jako zasada polityki w dziedzinie środowiska naturalnego). ${ }^{29}$

Przepisy prawa pochodnego UE odnoszące się do organizmów genetycznie zmodyfikowanych to Dyrektywa 2001/18/WE ${ }^{30}$ o zasadach uwolnienia GMO do środowiska, Rozporządzenie 1829/2003 ${ }^{31}$ W sprawie genetycznie zmodyfikowanej

${ }^{28}$ L. Caduff, T. Bernauer, Managing Risk and Regulation in European Food Safety Governance, „Review of Policy Research” January 2006, Vol. 23, Issue 1, s. 153, 155,-156.

${ }^{29}$ Traktat z Lizbony zmieniajacy Traktat o Unii Europejskiej i Traktat ustanawiający Wspólnotę Europejska podpisany w Lizbonie dnia 13 grudnia 2007 r., Dz. Urz. UE 2007/C 306/01.

${ }^{30}$ Dyrektywa Parlamentu Europejskiego i Rady 2001/18/WE z dnia 12 marca 2001 r. w sprawie zamierzonego uwalniania do środowiska organizmów zmodyfikowanych genetycznie i uchylajaca dyrektywę Rady 90/220/EWG, Dz. Urz. UE L 106, 17.4.2001.

${ }^{31}$ Rozporzadzenie (WE) nr 1829/2003 Parlamentu Europejskiego i Rady z dnia 22 września 2003 r. w sprawie genetycznie zmodyfikowanej żywności i pasz, Dz. Urz. UE L 268, 18.10.2003. 
żywności i pasz, Rozporządzenie 1830/200332 dotyczące wymogów śledzenia i etykietowania żywności i pasz transgenicznych, Dyrektywa 2015/412 zmieniająca Dyrektywę 2001/18/WE. ${ }^{33}$ Kolejnym instrumentem prawnym, istotnym z punktu widzenia zarówno zasad analizy i zarządzania ryzykiem, autoryzacji GMO lub żywności wyprodukowanej/zawierającej GMO oraz działania Europejskiego Urzędu ds. Bezpieczeństwa Żywności, jest Rozporządzenie 178/2002 ${ }^{34}$ określane jako Ogólne Prawo Żywnościowe UE. Należy też wymienić orzecznictwo sądów UE, które wnosi szczególny wkład m. in. w wykładnię zasady ostrożności i uznanie jej za jedną z ogólnych zasad prawa UE, która ma zastosowanie nie tylko do zagadnień ochrony środowiska naturalnego (tak jak to określono w art. 191 (2) TFUE), ale także stanowi podstawę przepisów o analizie i zarządzaniu ryzykiem w innych politykach (ochrona zdrowia ludzi, dobrostan zwierząt i roślin). ${ }^{35}$

Jak wcześniej wspomniano zasada ostrożności stanowi zwornik i jednocześnie podstawę przepisów o analizie/zarządzaniu ryzykiem w różnych politykach publicznych UE. Definicja tej reguły prawa jest zapisana w art. 191 (2) TFUE: „Polityka Unii w dziedzinie środowiska naturalnego stawia sobie za cel wysoki poziom ochrony, z uwzględnieniem różnorodności sytuacji w różnych regionach Unii. Opiera się na zasadzie ostrożności oraz na zasadach działania zapobiegawczego, naprawiania szkody w pierwszym rzędzie u źródła i na zasadzie ,zanieczyszczający płaci".

W Komunikacie Komisji na temat zasady ostrożności z 2000 r. ${ }^{36}$, skierowanym do PE, Rady i państw członkowskich wyjaśniono w jakim zakresie i kiedy Komisja Europejska uważa za uzasadnione odwołanie do zasady ostrożności w procesie podejmowania decyzji, których przedmiotem jest ryzyko. Choć stosowanie zasady ostrożności jest traktatowo ograniczone do problematyki ochrony środowiska naturalnego to zdaniem Komisji jak i Trybunału Sprawiedliwości UE ${ }^{37}$

${ }^{32}$ Rozporzadzenie (WE) nr 1830/2003 Parlamentu Europejskiego i Rady z dnia 22 września 2003 r. dotyczace możliwości śledzenia i etykietowania organizmów zmodyfikowanych genetycznie oraz możliwości śledzenia żywności i produktów paszowych wyprodukowanych z organizmów zmodyfikowanych genetycznie i zmieniajace dyrektywe 2001/18/WE, Dz. Urz. UE L 268, 18.10.2003.

${ }^{33}$ Dyrektywa Parlamentu Europejskiego i Rady (UE) 2015/412 z dnia 11 marca 2015 r. w sprawie zmiany dyrektywy 2001/18/WE w zakresie umożliwienia państwom czlonkowskim ograniczenia lub zakazu uprawy organizmów zmodyfikowanych genetycznie (GMO) na swoim terytorium, Dz. Urz. UE L 68, 13.3.2015.

${ }^{34}$ Rozporzadzenie (WE) 178/2002 Parlamentu Europejskiego i Rady z dnia 28 stycznie 2002 r. ustanawiajace ogólne zasady $i$ wymagania prawa żywnościowego, powolujące Europejski Urząd ds. Bezpieczeństwa Żywności oraz ustanawiające procedury w zakresie bezpieczeństwa żywności, Dz. Urz. UE L 31, 1.2.2002.

${ }^{35}$ C. Mereu, Schizophrenic Stakes of GMO Regulation in the European Union, "European Journal of Risk Regulation" 2012, Vol. 3, Issue 2, s. 204-208.

${ }^{36}$ Communication from the Commission on the Precautionary Principle, COM (2000) 1 final, Brussels, 2.2.2000.

${ }^{37}$ Zob.: The Queen v Ministry of Agriculture, Fisheries and Food, Commissioners of Customs \& Excise, ex p National Farmers' Union, Case C-157/96 [1998]. 
należy ją traktować jak zasadę ogólną prawa UE, na którą można powoływać się w przypadkach, kiedy dowody naukowe ewaluacji ryzyka są niepełne, niewystarczające i niepewne oraz kiedy wstępna analiza oparta o metody naukowe daje racjonalne podstawy do obaw i przewidywania, iż przyjęte środki zapobiegawcze mogą być niewystarczające. Powołanie się na zasadę ostrożności jest wtórne wobec naukowej oceny ryzyka. Ewaluacja ryzyka powinna być prowadzona przez wyznaczone gremia eksperckie i składać się z czterech faz: identyfikacja zagrożeń, charakterystyka zagrożeń, oszacowanie narażenia na konkretne czynniki oraz charakterystyka ryzyka. ${ }^{38}$ Niepewność naukowa jest skutkiem samej procedury ewaluacji ryzyka (np. zastosowana metoda badawcza, dane wzięte pod uwagę, techniki pomiaru itp.), ale również sprzeczności danych czy ich niekompletności. Nie można przystąpić do żadnych działań bez przeprowadzenia naukowej oceny ryzyka. Im mniej danych uzyskanych z analizy naukowej, tym większy poziom niepewności i tym bardziej zasadne powołanie się na zasadę ostrożności. ${ }^{39}$

Należy również zauważyć, iż zasada ostrożności nie dotyczy całości procesu analizy ryzyka, a uruchamiana jest dopiero na etapie zarządzania ryzykiem. Odwołanie się do niej nie zawsze musi oznaczać podjęcie konkretnych działań i ich implementację. Na tym etapie ma miejsce decyzja polityczna o działaniu lub zaniechaniu. W fazie zarządzania ryzykiem, kiedy dochodzi do implementacji decyzji opierających się na zasadzie ostrożności, nie można zapominać o tak ważnych zasadach jak proporcjonalność, niedyskryminacja, spójność (z przepisami przyjętymi wcześniej), badanie zysków i strat działania lub zaniechania oraz weryfikowanie postępów naukowych. ${ }^{40}$

Przyjęte w 2002 r. Rozporządzenie 178/2002 (Ogólne Prawo Żywnościowe - OPŻ) jest źródłem istotnych przepisów ujednolicających system kontroli i zarządzania bezpieczeństwem żywności na rynku wewnętrznym UE, w tym żywności genetycznie zmodyfikowanej. Na jego podstawie ustanowiono ogólne zasady, którymi muszą kierować się zarówno instytucje i organy UE, państwa członkowskie, jak również wszystkie osoby fizyczne i prawne działające na rynku wewnętrznym UE w sektorze żywnościowym. Można tu odnaleźć wyjaśnienie pojęć ryzyko „(...) niebezpieczeństwo zaistnienia negatywnych skutków dla zdrowia oraz dotkliwość takich skutków w następstwie zagrożenia", analiza

${ }^{38}$ Sąd (dawniej Sąd Pierwszej Instancji) w wyroku z 11 września 2002 r. w sprawie Pfizer Animal Health S. A. przeciwko Radzie Unii Europejskiej, T-13/99 precyzuje, że ewaluacja/ocena ryzyka powinna być oparta na priorytecie najwyższej jakości, przejrzystości i niezależności. Zdanie Sądu należy przykładać dużą wagę do jakości oceny naukowej, a zasada ostrożności może być uruchomiona tylko wtedy, kiedy wynikiem wnioskowania naukowego jest potwierdzenie występowania zagrożenia. Co ciekawe, Sąd jednocześnie przyzwala na odstępstwo od tej reguły przysługujące podmiotom zarządzającym ryzykiem, które w niektórych sytuacjach mogą dokonać derogacji powołując się na polityczną i demokratyczną legitymację instytucji UE.

${ }^{39}$ R. von Schomberg, The Precautionary Principle: Its Use Within Hard and Soft Law, „European Journal of Risk Regulation" 2012, Vol. 3, Issue 2, s. 151-153.

${ }^{40}$ Ibidem. 
ryzyka ,(..) proces składający się z trzech powiązanych elementów: oceny ryzyka, zarządzania ryzykiem i informowania o ryzyku”, ocena ryzyka ,(..) proces wsparty naukowo, składający się z czterech etapów: identyfikacji zagrożenia, charakterystyki niebezpieczeństwa, oceny ekspozycji i charakterystyki ryzyka", zarządzanie ryzykiem ,(...) proces...polegający na zbadaniu alternatywy polityki w porozumieniu z zainteresowanymi stronami, wzięciu pod uwagę oceny ryzyka $\mathrm{i}$ innych prawnie uzasadnionych czynników, i w razie potrzeby - na wybraniu stosownych sposobów zapobiegania i kontroli, informowanie o ryzyku, ,...) oznacza interaktywną wymianę informacji i opinii podczas procesu analizy ryzyka, dotyczącą zagrożeń i ryzyka, czynników związanych z ryzykiem i postrzeganiem ryzyka, między oceniającymi ryzyko, zarządzającymi ryzykiem, konsumentami, przedsiębiorstwami żywnościowymi i paszowymi, środowiskiem naukowym i innymi zainteresowanymi stronami" (art. 3 OPŻ).

Warto podkreślić, że zgodnie z przepisami OPŻ ocena ryzyka musi być oparta na dowodach naukowych, natomiast zarządzanie ryzykiem to etap, kiedy oprócz uwzględnienia wyników analiz naukowych, opinii Europejskiego Urzędu ds. Bezpieczeństwa Żywności (ang. European Food Safety Authority-EFSA), należy też wziąć pod uwagę zasadę ostrożności, o której mowa w art. 7 OPŻ. ${ }^{41}$ Co ważne, Rozporządzenie 178/2002 jest pierwszym aktem prawa pochodnego o mocy wiążącej, w którym zamieszczono definicję zasady ostrożności. ${ }^{42}$

Parlament Europejski i Rada w Rozporządzeniu 178/2002 powołują do życia nową agencję wspólnotową - Europejski Urząd ds. Bezpieczeństwa Żywności (EFSA), odpowiedzialną za doradztwo naukowe i wsparcie naukowo-techniczne we wszystkich obszarach związanych z bezpieczeństwem żywności i pasz. Jedną $z$ kompetencji EFSA jest opracowywanie opinii naukowych o produktach innych niż żywność i pasze, mających związek z GMO, zgodnie z definicją Dyrektywy 2001/18/WE (art. 22 (5c) OPŻ). EFSA jest agencją wspierającą wiedzą ekspercką instytucje UE, realizujące uprawnienia prawodawcze, pomaga Komisji Europejskiej $\mathrm{m}$. in. gdy konieczna jest interpretacja opinii dotyczących oceny ryzyka. Urząd jest odpowiedzialny na pierwszy etap procedury analizy ryzyka, czyli ocenę ryzyka, ale również za komunikowanie opinii publicznej o wynikach tej oceny (art. $23 \mathrm{OPZZ}) .^{43}$

${ }^{41} \mathrm{~W}$ szczególnych okolicznościach, gdy po dokonaniu oceny dostępnych informacji stwierdzono niebezpieczeństwo zaistnienia skutków szkodliwych dla zdrowia, ale nadal brak jest pewności naukowej, w oczekiwaniu na dalsze informacje naukowe umożliwiające bardziej wszechstronną ocenę ryzyka mogą zostać przyjęte tymczasowe środki zarządzania ryzykiem konieczne do zapewnienia wysokiego poziomu ochrony zdrowia określonego we Wspólnocie (art. 7 (1) OPŻ).

${ }^{42}$ L. DeFrancesco, How Safe Does Transgenic Food Need to Be?, "Nature Biotechnology" September 2013, Vol. 31, No. 9, s. 795.

${ }^{43}$ Szerzej o polityce otwartości i wymogach komunikowania opinii publicznej o działaniach EFSA związanych z oceną ryzyka GMO: S. Hartley, K. M. Millar, The Challenges of Consulting the Public on Science Policy: Examining the Development of European Risk Assessment Policy for Genetically Modified Animals, „Review of Policy Research” 2014, Vol. 31, No. 6, s. 489, Por.: F. Janning, Risk Regulation without Political Conflicts? Regime Structures in Food Safety Politics in Germany, Great Britain and the Netherlands, "German Policy Studies" 2008, Vol. 4, No. 1, s. 79. 
Na EFSA spoczywa obowiązek opracowania i uruchomienia procedur systematycznego poszukiwania, zbierania i analizowania informacji i danych o potencjalnym ryzyku. W realizacji tego zadania EFSA współpracuje z właściwymi organami państw członkowskich, innymi agencjami UE oraz Komisją Europejską, prosząc je o przekazanie informacji w sytuacji kiedy Urząd ma podejrzenia, że ryzyko może wystąpić. Pozyskaną wiedzę EFSA przekazuje Parlamentowi Europejskiemu, Komisji i państwom członkowskim (art. 34 OPŻ). Dla bardziej efektywnego reagowania tworzy się system wczesnego ostrzegania, który służy jako kanał przekazywania informacji EFSA. System wczesnego ostrzegania o zagrożeniach dla zdrowia ludzi pochodzących z żywności tworzą państwa członkowskie, EFSA i Komisja, która zarządza siecią. Wszelkie informacje o zagrożeniach przekazuje się Komisji, która niezwłocznie zawiadamia pozostałych członków systemu. Działania EFSA skupiają się na dostarczeniu kompleksowej wiedzy naukowej i technicznej, dzięki której możliwe będzie skuteczne zarządzanie ryzykiem (art. 50 OPŻ). Ponadto, w sytuacjach kiedy wiadomo, że skala zagrożenia przekracza możliwości poradzenia sobie z nim środkami dostępnym na poziomie państwowym, Komisja z własnej inicjatywy lub na wniosek państwa członkowskiego może przyjąć następujące środki: zawieszenie wprowadzania na rynek lub spożywania żywności/paszy, ustanowienie specjalnych warunków dla określonej żywności/paszy lub inne środki tymczasowe. Podobnie w przypadku produktów importowanych (art. $53 \mathrm{OPZZ}$ ). Komisja przygotowuje, po konsultacji z państwami członkowskimi i EFSA plan zarządzania kryzysami żywnościowy$\mathrm{mi}^{44} \mathrm{~W}$ sytuacji wystąpienia poważnego ryzyka dla zdrowia ludzi, któremu nie da się zapobiec, wyeliminować czy zredukować stosując obowiązujące przepisy, Komisja powołuje jednostkę kryzysową, w której skład wchodzi EFSA (art. 56 OPŻ). W opisanych powyżej sytuacjach Komisja podejmuje decyzje przyjmując akty o charakterze wykonawczym w procedurze komitologicznej. Jest w tym wspierana przez Stały Komitet ds. Łańcucha Pokarmowego i Zdrowia Zwierząt (komitet komitologiczny składający się z przedstawicieli państw członkowskich, kierowany przez Komisję). ${ }^{45}$

Akty prawodawcze o charakterze szczegółowym, w których można znaleźć zasady i procedury analizy ryzyka GMO to przede wszystkim Dyrektywa 2001/18/WE o zamierzonym uwolnieniu GMO do środowiska oraz Rozporządzenie 1829/2003 w sprawie genetycznie zmodyfikowanej żywności i pasz. Celem Dyrektywy 2001/18/WE jest zbliżanie przepisów ustawowych, wykonawczych

${ }^{44}$ Szczegółowe rozwiązania prawne dotyczące przyjęcia planu ogólnego zarządzania kryzysami żywnościowymi lub paszowymi zostały określone przez Komisję w Decyzji (2004/478/WE) Komisji z dnia 29 kwietnia 2004 r. dotyczącej przyjęcia planu ogólnego zarządzania kryzysami żywnościowymi/paszowymi, Dz. Urz. UE L 160, 30.4.2004.

${ }^{45}$ Szerzej na temat procedury komitologicznej w Rozporzadzenie Parlamentu Europejskiego i Rady (UE) Nr 182/2011 z dnia 16 lutego 2011 r. ustanawiające przepisy i zasady ogólne dotyczace trybu kontroli przez państwa członkowskie wykonywania uprawnień wykonawczych przez Komisje, Dz. Urz. UE L 55, 28.2.2011. 
i administracyjnych państw członkowskich oraz ochrona zdrowia ludzi i środowiska naturalnego. Wszystkie działania podejmowane na podstawie jej przepisów powinny być zgodne z zasadą ostrożności (art. 1 Dyr. 2001/18/WE). Zakres przedmiotowy obowiązywania Rozporządzenia 1829/2003 jest ograniczony do stosowania GMO jako żywność i pasze transgeniczne. Jednak oddziaływanie prawne nie ogranicza się tylko do funkcjonowania wspólnego rynku (tak jak w przypadku dyrektywy), ale również innych polityk szczegółowych: ochrona zdrowia, ochrona konsumentów, środowisko naturalne, polityka rolna. ${ }^{46}$

W obu aktach prawodawczych tworzy się system autoryzacji organizmów genetycznie zmodyfikowanych $\mathrm{w}$ celu wprowadzenia ich do obrotu lub przeprowadzenia zamierzonego uwolnienia do środowiska naturalnego - w przypadku Dyrektywy 2001/18/WE, czy wprowadzenia do obrotu żywności/pasz transgenicznych - w przypadku Rozporządzenia 1829/2003. Uwolnienie GMO do środowiska to np. wprowadzenie do sprzedaży nasion roślin transgenicznych, ale także wykorzystanie w badaniach polowych. Dlatego ocena ryzyka jest skierowana na wpływ GMO na środowisko naturalne, gdzie w Rozporządzeniu 1829/2003 wykracza znacznie poza badanie oddziaływania na ekosystem. Przepisy dyrektywy nakładają na państwa członkowskie obowiązek przeciwdziałania negatywnym efektom uwolnienia lub wprowadzenia GMO do obrotu dla zdrowia ludzi i zwierząt. W rozporządzeniu rozszerzono ten katalog o zakaz wprowadzania w błąd oraz wprowadzania do obrotu takiej żywności, która może powodować niekorzystne skutki odżywcze dla konsumentów. Co istotne, adresatem tych wymogów nie jest państwo członkowskie, ale podmiot wnioskujący o autoryzację żywności/paszy transgenicznej. Kolejną różnicą pomiędzy omawianymi aktami jest procedura autoryzacji GMO. W rozporządzeniu przewidziano scentralizowany model procedury, gdzie decyzja podejmowana jest na poziomie wspólnotowym w zgodzie z zasadą ,jedne drzwi - jeden klucz". Zainteresowany podmiot składa wniosek do właściwego organu krajowego, który informuje i udostępnia wniosek EFSA, ta przekazuje informacje pozostałym państwom i Komisji wraz z udostępnieniem wniosku oraz publikuje streszczenie dossier (art. 5 Rozp. 1829/2003). EFSA opiniuje wniosek i w ramach tej kompetencji, na podstawie delegacji wtórnej, może zwracać się do właściwych organów państw członkowskich o przeprowadzenie oceny bezpieczeństwa żywności/paszy, będącej przedmiotem wniosku o autoryzację (art. 6 (b) Rozp. 1829/2003). Weryfikacja wniosku przez EFSA kończy się przesłaniem sprawozdania z procesu oceny oraz uzasadnienie opinii do Komisji, państw członkowskich i wnioskodawcy. Warto podkreślić, że system oceny wniosku ma charakter wielopoziomowy, gdyż EFSA współdziała $\mathrm{z}$ wnioskodawcą, który proponuje metody wykrywania i weryfikacji, następnie badane i uwierzytelniane przez wspólnotowe laboratorium referencyjne (art. 32 - nałożenie na wnioskodawcę obowiązku partycypacji w kosztach wypełniania

${ }^{46}$ S. Borrás, Legitimate Governance of Risk at the EU Level? The Case of Genetically Modified Organisms, “Technology and Social Risk” January 2006, Vol. 73, Issue 1, s. 64. 
zadań przez wspólnotowe laboratorium referencyjne i Europejską Sieć Laboratoriów GMO) oraz konsultuje się z właściwym organem krajowym wyznaczonym przez państwo członkowskie (art. 6 (3d), 4). Ostateczna decyzja o autoryzacji podejmowana jest przez Komisję w procedurze komitologicznej, po konsultacji ze Stałym Komitetem ds. Łańcucha Pokarmowego i Zdrowia Zwierząt (art. 7, 35 Rozp. 1829/2003).

Nadzór nad właściwym realizowaniem zezwolenia oraz monitorowanie GMO po wprowadzeniu do obrotu spoczywa na posiadaczu zezwolenia. On także jest zobowiązany do składania sprawozdania $\mathrm{z}$ wykonywania zezwolenia bezpośrednio do Komisji. Ponadto na posiadaczu zezwolenia spoczywa odpowiedzialność za przekazywanie do Komisji wszelkich nowych informacji technicznych i naukowych dotyczących oceny ryzyka produktu, będącego przedmiotem zezwolenia. Musi też przekazywać Komisji informacje o zakazach i ograniczeniach wprowadzonych w państwach członkowskich, w których GMO jest na rynku (art. 9, 21 Rozp. 1829/2003). Podmiot wnioskujący po uzyskaniu zezwolenia może je egzekwować we wszystkich państwach członkowskich UE i wprowadzać żywność/paszę GMO na wewnętrzny rynek UE.

Odmienne rozwiązanie przyjęto w Dyrektywie 2001/18/WE, gdyż w tym przypadku ustawodawca wspólnotowy postanowił utrzymać w mocy stary system autoryzacji GMO, wprowadzony przepisami Dyrektywy 90/220 ${ }^{47}$ Wnioskodawca, chcąc uzyskać zezwolenie na uwolnienie/wprowadzenie do obrotu GMO, kieruje wniosek do właściwego organu państwowego w państwie członkowskim, w którym ma nastąpić pierwsze uwolnienie GMO do środowiska lub wprowadzenie do obrotu. Na podmiocie zgłaszającym spoczywa odpowiedzialność za przeprowadzenie oceny ryzyka dla środowiska naturalnego zgodnie z wymogami zapisanymi w Załączniku II $^{48}$ do dyrektywy. Odrębnym przypadkiem są GMO

${ }^{47}$ Council Directive 90/220/EC of 23 April 1990 on the deliberate release into the environment of genetically modified organisms, OJ L 7, 10.1.1991.

${ }^{48}$ Zdefiniowano tu rodzaje skutków, jakie może wywołać uwolnienie/wprowadzenie GMO. Wymienia się skutki bezpośrednie i pośrednie oraz natychmiastowe i opóźnione. Zasadą jest też przeprowadzanie analizy kumulacyjnych skutków długoterminowych, które oznaczają skumulowane skutki wydawanego zezwolenia dla zdrowia ludzi i ekosystemu, np. dla flory i fauny, żyzności gleb, erozji gleb, łańcuchów pokarmowych, różnorodności biologicznej, zdrowia ludzkiego i zagadnień związanych z odpornością na antybiotyki. Ocena ma charakter indywidualny wg. zasady case-by-case. Elementem oceny ryzyka jest też konieczność określenia czy potrzebne jest uruchomienie działań w ramach zarządzania ryzykiem. Ocena ryzyka ma być prowadzona w oparciu o dostępne dane naukowo-techniczne. Ewaluacja opiera się na zasadzie analizy procesu prowadzącego do powstania GMO (proces-based analysis), w odróżnieniu od modelu stosowanego m. in. w USA, czyli tzw. product-based analysis. Ocena odbywa się w kilku etapach: określenie cech, które mogą mieć wpływ na wystąpienie niepożądanych skutków i ich konsekwencji, ocena prawdopodobieństwa wystąpienia każdego zidentyfikowanego, potencjalnego skutku niepożądanego, szacunkowa ocena ryzyka powodowanego przez każdą zidentyfikowaną cechę danego GMO, zastosowanie strategii opanowania zagrożeń wynikających z zamierzonego uwolnienia lub wprowadzenia do obrotu GMO, określenie całkowitego zagrożenia powodowanego przez GMO (z uwzględnieniem wszystkich zaproponowanych strategii zarządzania ryzykiem (załącznik II, 
zawierające geny kodujące odporność na antybiotyki, gdyż tu dodatkowo nadzór nad oceną zagrożeń dla środowiska sprawują państwa członkowskie i Komisja. Według regulacji dyrektywy ciężar weryfikacji przeprowadzonej oceny oraz późniejszych inspekcji i weryfikacji wyników, jak również przyjęcie procedur tzw. śledzenia produktu na rynku spoczywa na państwach i ich właściwych organach (art. 4 Dyr. 2001/18/WE). ${ }^{49}$

Stworzony tu system zatwierdzenia GMO opiera się o model decydowania „bottom - up”, gdzie w przypadku Rozporządzenia 1829/2003 mieliśmy do czynienia z modelem „top - down”. Przyznać jednak należy, że nie są to wzorcowe przykłady obu modeli. Decyzję o zezwoleniu na uwolnienie/wprowadzenie do obrotu GMO podejmuje właściwy organ krajowy. Przepisy dyrektywy przewidują także możliwość skorzystania z tzw. procedur zróżnicowanych (art. 7 Dyr. 2001/18/WE), ale jest to ograniczone do tych GMO, co do których „(...) uzyskano wystarczające doświadczenie w zakresie uwalniania określonych GMO do określonych ekosystemów". Podobnie, po przekazaniu informacji właściwemu organowi państwowemu lub Komisji z dokonanej oceny wniosku o zezwolenie mogą one zgłaszać zastrzeżenia lub sprzeciw (art. 18). Jeśli sprzeciw właściwego organu lub Komisji zostanie utrzymany decyzja jest podejmowana przez Komisję w procedurze komitologicznej (art. 30 (2) Dyr. 2001/18/WE). To istotne, ponieważ w dotychczasowej praktyce stosowania przepisów dyrektywy za każdym razem zgłaszany jest sprzeciw, co skutkuje przeniesieniem decydowania z poziomu krajowego na poziom wspólnotowy. ${ }^{50}$

Z inicjatywy Komisji tworzony jest system wymiany informacji o zezwoleniach wydanych w poszczególnych państwach, co stanowi ponadnarodową płaszczyznę współpracy, w ramach której Komisja pełni funkcje wykonawcze. Odpowiedzialność za monitorowanie i składanie sprawozdań spoczywa na zgłaszającym, który przekazuje informacje Komisji i państwom członkowskim (art. 20). Państwom przysługuje też prawo tymczasowego ograniczenia lub wprowadzenia zakazu stosowania i/lub sprzedaży GMO na swoim terytorium. Skorzystanie z klauzuli ochronnej jest jednak możliwe dopiero wtedy, gdy zaistnieją nowe lub dodatkowe informacje mające wpływ na ocenę ryzyka lub dokonana zostanie weryfikacja wcześniejszej wiedzy w wyniku nowych/dodatkowych danych naukowych. Podstawowym kryterium jest dowód naukowy. Tutaj również obowiązuje wymóg decydowania wspólnotowego w procedurze komitologicznej. Uzupełnieniem tych przepisów i jednocześnie odpowiedzią ustawodawcy wspólnotowego

Dyr. 2001/18/WE). Zob.: T. Assmuth, M. Hildén, Ch. Benighaus, Integrated Risk Assessment and Risk Governance as Socio-political Phenomena: Synthetic View of the Challenges, ,Science of the Total Environment" 2010, Vol. 408, DOI:10.1016/j.scitotenv.2009.11.034, s. 3944.

${ }^{49}$ M. Weimer, Applying Precaution in EU Authorisation of Genetically Modified Products Challenges and Suggestions for Reform, „European Law Journal” September 2010, Vol. 16, No. 5, s. 635 .

${ }^{50}$ V. Paskalev, Can Science Tame Politics: The Collapse of the New GMO Regime in the EU, „European Journal of Risk Regulation” 2012, Vol. 3, Issue 2, s. 192. 
na utrzymujące się kontrowersje wokół GMO, blokowanie procesu decyzyjnego i rozbieżność stanowisk państw członkowskich jest Dyrektywa 2015/412 zmieniająca Dyrektywę 2001/18/WE, a konkretnie dodająca do art. 26 punkty a, b i c. Zgodnie z nowymi regulacjami państwa członkowskie mają prawo by wykluczyć z uprawy odmian roślin transgenicznych całość lub część terytorium. Wniosek tego dotyczący państwo przekazuje do Komisji, która rozpowszechnia go wśród pozostałych państw oraz wysyła do zgłaszającego/wnioskodawcy. Nowością jest, że jako podstawę do ograniczenia upraw lub zakazania na całości lub części terytorium państwa kultywacji danego GMO mogą być argumenty nie do końca mające związek z uwarunkowaniami naukowymi czy technicznymi. Są to cele polityki ochrony środowiska, zagospodarowanie przestrzenne w miastach i na obszarach wiejskich, użytkowanie gruntów, skutki społeczno-gospodarcze, unikanie obecności GMO w innych produktach, cele polityki rolnej lub związane z polityką publiczną. Wymienione podstawy nie mogą jednak kolidować z oceną ryzyka dla środowiska prowadzoną w oparciu o wytyczne Dyr. 2001/18/WE i Rozp. 1829/2003. Należy też pamiętać, iż ten instrument renacjonalizacji kompetencji decyzyjnych jest ograniczony w stosowaniu wyłącznie do uprawy GMO, a nie dotyczy obrotu GMO na rynku wewnętrznym.

\section{PODSUMOWANIE}

Tworzony od początku lat 90. XX wieku wspólnotowy system oceny, zarządzania i komunikacji o ryzyku związanym z organizmami genetycznie zmodyfikowanymi jest powszechnie uważany za restrykcyjny. Stanowi on z jednej strony odzwierciedlenie nastrojów panujących wśród mieszkańców państw członkowskich UE, którzy są sceptyczni wobec komercjalizacji produktów transgenicznych, jak również znacznego upolitycznienia debaty publicznej toczącej się wokół GMO. $\mathrm{Z}$ drugiej strony, system ten wyraża starania instytucji UE do tworzenia prawa, które będzie godziło społeczne nastroje z wymogami prawa UE, a szczególnie zobowiązaniami prawnomiędzynarodowymi UE czy pozostałymi zasadami prawnymi np. odnoszącymi się do funkcjonowania rynku wewnętrznego UE, poszanowania swobody przepływu towarów czy polityki rolnej UE.

Wartością nadrzędną oraz zasadą prawną i instytucjonalną jest zasada ostrożności, która znajduje zastosowanie w fazie zarządzania ryzykiem, zawsze wtedy, gdy niemożliwe jest udowodnienie naukowe braku zagrożenia lub wyniki badań są niespójne, niepełne czy wykluczają się. Czynnik niepewności naukowej jest uzasadnieniem dla przezorności decyzyjnej.

Dotychczas wypracowany dorobek legislacyjny, orzecznictwo sądów europejskich oraz doświadczenia wynikające z implementacji zasad zarządzania ryzkiem GMO w UE pozwala sformułować kilka wniosków dotyczących wyłaniającego się modelu zarządzania ryzykiem technologicznym. Ewaluacja i zarządzanie ryzykiem GMO w UE to przykład policentrycznego zarządzania, 
w którym uczestniczą podmioty ponadpaństwowe (instytucje UE, agencje UE, grupy robocze, komitety naukowe), narodowe (organy właściwe państw członkowskich), podmioty transnarodowe (zrzeszenia regionów, międzynarodowe wspólnoty epistemiczne, grupy interesu) oraz osoby fizyczne i prawne. Proces decyzyjny przebiega w wymiarach zarówno bottom-up, jak też top-down. Mamy do czynienia z horyzontalnym i wertykalnym podziałem kompetencji i uprawnień. Na poziomie wspólnotowym akty prawne o charakterze podstawowym przyjmowane są w zwykłej procedurze prawodawczej, a wykonawcze w procedurze komitologicznej. Pomimo tego, że przynajmniej w niektórych przypadkach decyzje mogą być podejmowane na poziomie właściwych organów państw członkowskich to z uwagi na silną polaryzację stanowisk, upolitycznienie procesu decyzyjnego i w konsekwencji jego blokowanie uprawnienie to we wszystkich dotychczasowych przypadkach było realizowane przez Komisję Europejską, działającą w oparciu o opinie naukowe EFSA.

Ten fakt jest przedmiotem ostrej krytyki. Komisji zarzuca się, że w swoim decydowaniu bierze pod uwagę wyłącznie opinię EFSA o poziomie ryzyka, a pomija inne argumenty. Nie można jednak zapominać, że obecnie obowiązujący i tak krytykowany system zyskał akceptację większości państw członkowskich, które przegłosowały go kwalifikowaną większością w Radzie, aby później go blokować. W działaniach Komisji można również odnaleźć wiele sprzeczności. Z jednej strony Komisja wspiera system oparty na naukowej ocenie ryzyka i współdziała aktywnie z EFSA, co stanowi wypełnienie jej traktatowych zadań, jakimi są wspieranie właściwego funkcjonowania rynku wewnętrznego UE i promocja współpracy gospodarczej pomiędzy państwami członkowskimi. Z drugiej strony, odnotować można przeciwny trend w działaniu Komisji, której zdarza się w nieuzasadniony sposób nadmiernie przedłużać proces autoryzacji nowych GMO lub odwoływać się do zasady ostrożności, stosując jej rygorystyczną interpretację w przypadkach, co do których wiadomo, że nie stanowią zagrożenia. Ta niespójność bierze się stąd, że Komisja podejmuje decyzje w trudnych warunkach, opierając się tylko na opinii EFSA, której działalność coraz częściej jest również przedmiotem krytyki. Jednak rodzi się pytanie, w jaki inny, alternatywny sposób oceniać ryzyko niż przy użyciu metod stosowanych w naukach ścisłych i przyrodniczych. Ani Komisja, ani podmioty, z którymi współpracuje nie zostały do tej pory wyposażone w metodologię pozwalającą na uwzględnienie w ocenie ryzyka czynników społecznych, etycznych czy ekonomicznych, za czym głośno postulują środowiska sceptycznie nastawione do nowoczesnej biotechnologii. Jak na razie model zarządzania GMO obowiązujący w UE jest niedemokratyczny, gdyż autoryzacja GMO odbywa się przy sprzeciwie części państw i jest dokonywana przez Komisję, będącą instytucją ponadnarodową reprezentującą interes UE. 


\title{
RISKS MANAGEMENT OF GENETICALLY MODIFIED ORGANISMS IN THE EUROPEAN UNION
}

\begin{abstract}
Genetically modified organisms' development and commercialization has been a subject of public debate for almost two decades. The risk of GMO commercialization, irreversibility, and unpredictable long-term consequences have been of special interest. Thus, risk analysis and risk governance are perceived as a state-of-the-art issue in terms of a norm setting process. This article analyses the legal solutions for regulating GMOs' risk governance introduced in the European Union. EU legislation in the area of GMOs is an example of a stringent model of risk governance based on the precautionary principle and the dispersal of competencies between supranational, state, regional, and individual levels. The aforementioned model is an example of both Europeanization with a spill-over effect and counter-Europeanization. Moreover, the model can be defined as polycentric governance, where horizontal and vertical integration is present.
\end{abstract}

Key words: genetically modified organisms, European Union, risk governance, precautionary principle 